\title{
Gendered Characteristics of Female Learners' Conversational Japanese
}

\author{
Maki Yoshida \\ Monash University
}

\begin{abstract}
This study examines gendered characteristics in four female Japanese language learners' discourse practices in a communicative setting, where they interact with native Japanese speaking friends in a JFL context. Focusing on the relationship between gender ideologies and discourse practices, I explore the extent to which learners are aware of gender ideologies in the Japanese community and how these ideologies are influential in their discourse practices in the particular setting. In addition, how native speakers of Japanese evaluate gender-differentiated features produced by the learners during the interaction is investigated.

Qualitatively-approached, this study revealed that each learner possesses a unique character in their utterances and perceptions, reflecting their individual awareness of gender ideologies and their negotiation of language use against the backdrop of social expectations. At the same time, a lack of such awareness emerged as an issue which kept them from fully and actively engaging in exploring their subjectivities. In addition, this study pointed out that native Japanese speakers utilised gender ideologies as the basis for their judgements on learners' gendered features in their interaction.
\end{abstract}

\section{Keywords}

Gender, Identity, Ideology, JFL, Contact Situation

\section{Introduction}

Among the many languages utilised for communication, Japanese is one language where gender differences are prominent. ${ }^{1}$ A great variety of linguistic features as well as paralinguistic features in Japanese distinguish the gender identity of the speaker or the referent to some degree. ${ }^{2}$

\footnotetext{
Reynolds, 'Gengo to sēsa no kenkyū - genzai to shōrai'; Abe, 'Mottomo sēsa no aru gengo - gengo no sēsa no tajūkōzō.'

2 Ide, Onna no Kotoba Otoko no Kotoba; Shibamoto, Japanese Women's Language; Mizutani and Mizutani, How to be Polite in Japanese; McGloin, 'Sex
} difference and sentence-final particles'; Okamoto, 'Social context, linguistic ideology, and indexical expressions in Japanese'; Iwasaki, Japanese. 
A traditional approach to gender differences has been to categorise various features of the Japanese language into men's and women's language. Studies interested in such categorisation of gendered Japanese claim that men's language is linked with images of authority, roughness, and straightforwardness; while women's language expresses femininity by giving speech an impression of kindness, gentleness and softness. ${ }^{3}$ Such gender differences have been identified in various features such as pronouns, vocabulary, frequency in the use of honorifics, pitch height, intonation, and sentence-final particles (SFPs). ${ }^{4}$

Recent focus on gendered language has shifted toward varieties in actual discourse practices, not simply tied to traditional categories of men's and women's language. These studies utilise empirical data rather than researchers' introspection, which former studies were likely to rely on, ${ }^{5}$ to examine speakers' discourse practices in relation to identities. Consequently, a great number of variables in actual speech have been identified. ${ }^{6}$ In addition, how gendered features in speech of this era differ from that of previous decades has also received attention, with some studies indicating neutralisation of gender differences in Japanese. ${ }^{7}$

Despite wide interest in gender differences in Japanese as a first language, few studies have been conducted on aspects linked to learners of Japanese, especially those who are studying Japanese as a foreign language (JFL). Thomson and Iida, for example, conducted a consciousness survey on gender differences in Japanese on a large scale, targeting learners at universities in Australia. ${ }^{8}$ They established that awareness of gender differences varied among the students, as did their perceptions of them. Furthermore, they found that learners are willing to learn about differences on the whole, contrary to the authors' expectations. They concluded that elements such as the learner's level, their backgrounds, and the length of time in Japan influenced the result. Similarly, Asada investigated learner's awareness towards gender differences in Japanese, focusing on SFPs. ${ }^{9}$ Comparing perceptions of some SFPs between learners of JFL and native speakers of Japanese of their own age, he concluded that learners were aware of the gender differences that these SFPs indicated and that these perceptions were similar to those of native speakers. He further examined how learners utilise SFPs in their conversation

\footnotetext{
Ide, op. cit.

4 Ide, op. cit.; Shibamoto, op. cit.; Iwasaki, op. cit.; Ohara, 'Shakai onsēgaku no shiten kara mita Nihonjin no koe no kōtë,' 'Finding one’s voice in Japanese: a study of the pitch levels of L2 users'.

5 Okamoto and Shibamoto,'Introduction'.

6 See Abe, 'Lesbian bar talk in Shinjuku, Tokyo'; Okamoto, “Tasteless" Japanese: less "feminine” speech among young Japanese women', 'Social context, linguistic ideology, and indexical expressions in Japanese'; SturtzSreetharan, 'Japanese men's linguistic stereotypes and realities: conversations from the Kansai and Kanto regions', 'Gentlemanly gender?: Japanese men's use of clause-final politeness in casual conversations'.

Mizutani and Mizutani, op. cit.

Thomson and Iida, 'Nihongo kyōiku ni okeru sēsa no gakushū - Ōsutoraria no gakushūsha no ishiki chōsa yori - '

Asada, 'Daini gengo to shite no Nihongo no otoko kotoba, onna kotoba - danjosa wo shimesu bunmatsu hyōgen ni oite no Nihongo gakushūsya no sansyutsu, juyō nōryoku - :
} 
amongst other learners in a rather controlled setting. Participants in his study were provided with certain topics to talk about and were instructed to communicate in $d a$-style: one of the speech styles where more gendered-SFPs are expected to appear. According to Asada, despite learners' awareness of gender differences in SFPs, very few SFPs appeared in their production. ${ }^{10}$

Previous studies have examined gender differences in Japanese from different perspectives. Although the importance of interrelating gender, language and identity has become more recognised in the area of gender studies, ${ }^{11}$ be it first, second, or additional language(s), such an approach in relation to learners in the JFL setting has received little attention to date. In addition, the actual language use of learners of Japanese concerning gender differences has been relatively unexplored utilising qualitative methods. Motivated by this rationale, this study investigates gendered characteristics in learners' discourse practices in a communicative setting, where they interact with native Japanese speaking friends in a JFL context. Moreover, this paper aims to examine the setting qualitatively in order to obtain deeper understandings of learners' gendered language choices expressed in their discourse. Specifically, the following questions are addressed:

1. What kind of gendered features occur in Japanese discourse in the setting of interaction between advanced learners of Japanese and their native Japanese speaking friends?

2. How do the native speakers evaluate the learners' gendered discourse in their interaction?

3. How aware are the learners of Japanese gender ideologies? 


\section{Conceptual Framework}

The present study employs Nakamura's Dynamic Model of Language and Gender Studies as a means to investigate the (non-)appearance of gendered features in communicative settings (see Fig. 1). ${ }^{12}$

\begin{tabular}{c}
\hline Gender Relations (Social Structures) \\
$\downarrow \uparrow$ \\
\hline Gender Ideologies (Discourse Orders) \\
$\downarrow \quad \uparrow$ \\
\hline Gender Identities (Discourse Practices) \\
\hline
\end{tabular}

Figure 1: Dynamic Model of Language and Gender Studies ${ }^{13}$

This model conceptualises the dialectic relationship among three facets of language and gender. ${ }^{14}$ Nakamura defines gender relations (social structures) as the gender-related power structures in society; gender ideologies (discourse orders) as gender-related categories, social subjects, social relationships, and conceptual frameworks, which have been historically constituted and ordered by previous discourse practices; and gender identities (discourse practices) as a variety of gender-related identities that subjects actively (re)construct in discourse practices. ${ }^{15}$

According to Nakamura's model, so-called 'men's language' and 'women's language' function as gender ideologies in the community where the language is spoken. Previous studies have identified gendered features in Japanese and classified these features into these two categories, namely male and female language. In this study, I draw on Shibamoto's traditional framework in order to examine characteristics of gendered features appearing in the target setting. ${ }^{16}$ Among the categories in which she indicates the appearance of gender-differentiated features in Japanese, the current study focuses on choice of verb endings, pronouns, lexical forms, and SFPs. In addition, the form of request/command is included as another feature where gender differences emerge in Japanese. ${ }^{17}$

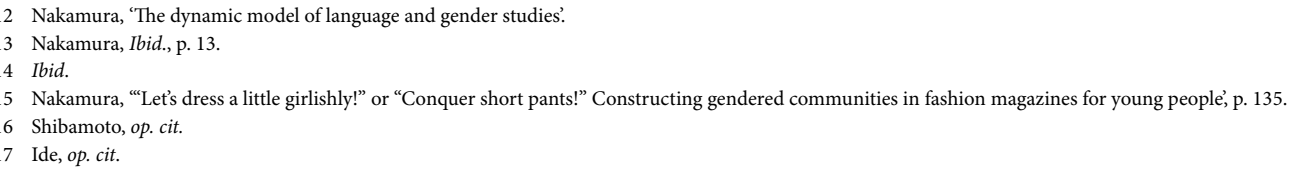


Nakamura argues that these gender ideologies consist of stereotypical images of how men and women should talk, which have been historically formed by members of the community. ${ }^{18}$ Therefore, they do not necessarily conform to how men and women actually talk, by which she concludes that such language categories formed as a result of gender ideologies should be distinguished from actual discourse practices. She further indicates that gender ideologies play a role in restricting and providing resources to individuals in their discourse practices. As a consequence of these gender ideologies being considered 'the norm' ${ }^{19}$ in the community, one expresses oneself by either accepting or resisting the social expectations as an active agent by constructing one's identities and relationships. ${ }^{20}$ She argues that individuals do not follow gender ideologies submissively but negotiate their language use vis-à-vis hegemonic norms. Such negotiation, therefore, accounts for variations in their everyday discourse practices beyond simple binary categories of 'men's language' and 'women's language'.

By distinguishing gender ideologies and discourse practices and shedding light on the negotiation of language use by individuals, the Dynamic Model of Language and Gender Studies enables the current study to explore the gendered characteristics of learners' discourse practices at multiple levels. In the present study, I am interested in the extent to which learners are aware of gender ideologies in the Japanese community and how these ideologies are influential as resources and restrictions in their discourse practices in a particular context, namely, conversations with close native speakers of Japanese. Although the model is not specifically addressed to learners of Japanese, I apply the framework on the basis that learners are learning gender ideologies as one aspect of Japanese, which would influence their speech in some form.

\section{Methodology}

\section{Participants}

The present study involves four pairs, with each pair consisting of a learner of Japanese at the advanced level and her close native Japanese-speaking friend. Although unintended, all of the participants employed in this study were female. They were enrolled in an Australian university at the time the study was conducted. I focused on learners at advanced levels since these learners are expected to be more familiar with a wider variety of different conversational language features in Japanese, compared to those at lower levels. The background of these pairs is presented in Table 1 below.

18 Nakamura, 'The dynamic model of language and gender studies'; "Let's dress a little girlishly!" or "Conquer short pants!" Constructing gendered communities in fashion magazines for young people?.

19 Nakamura, "Let's dress a little girlishly!” or "Conquer short pants!" Constructing gendered communities in fashion magazines for young people', p. 135.

20 Okamoto, “'Tasteless" Japanese: less “feminine” speech among young Japanese women', p. 321. 


\section{Procedure}

Three different kinds of methods were employed in this study for data collection: questionnaires, audio-recording of an interaction, and semi-structured interviews. Learners were asked to fill in a short questionnaire regarding their language background and previous Japanese study. In order to examine what kind of gendered features appear in interactive settings, I asked the participants to converse about any topic while having their conversation audio-recorded for approximately ten minutes. I was not present at the time of the recording to avoid influencing the conversation of the participants.

Immediately after the recording, the informants participated in a face-to-face interview with the researcher individually, which lasted 40 to 90 minutes. The first half of the interview employed a stimulated-recall interview method in order to investigate perceptions by the participants towards gendered features which occurred in the recorded conversation. Neustupný advocates this kind of interview, which he calls a 'follow-up interview', arguing that it is a valuable method to understand the participants' cognitive processes in 'contact situations. ${ }^{21}$ According to the author, in many cases these processes are not observable at the surface level. ${ }^{22}$

Immediately following the stimulated-recall interview, a semi-structured interview was conducted to explore the role that gender ideologies play in the participants discourse practices. I aimed at examining how aware learners were of these gender ideologies and their influence in the communicative setting. In addition, learners were asked about the construction of these ideologies. Finally, gender ideologies that native speakers of Japanese possess were focused on as well, in order to investigate to what extent they utilised these ideologies when they evaluated gendered features in learners' discourses in the preceding stimulated-recall interview. 


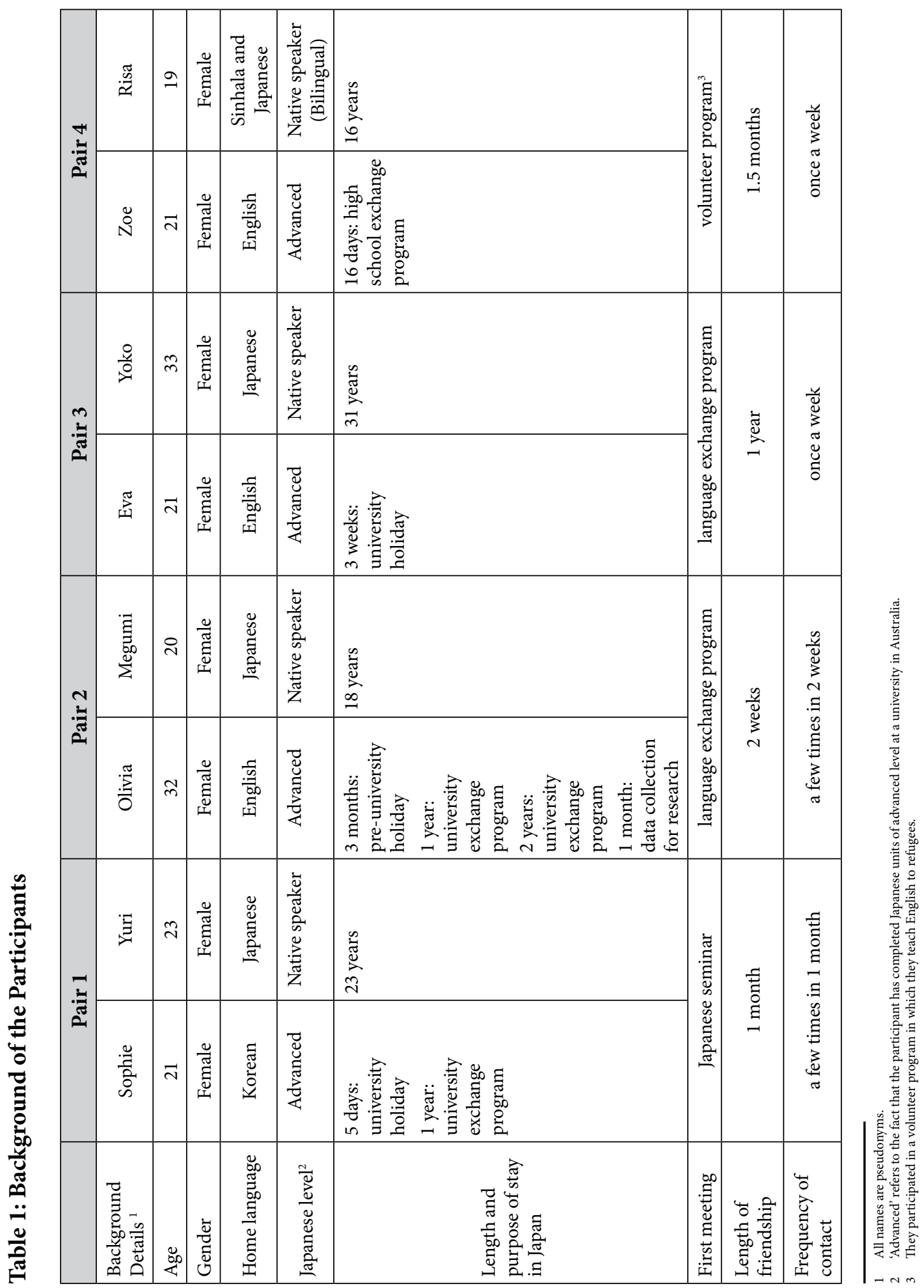




\section{Data Analysis}

The current study identified several gendered features in Japanese that appeared in learners' discourse practices. This section closely examines each feature, indicating the background against which these characteristics appeared and how these articulations were evaluated by the learners' native Japanese speaking interlocutors. Subsequently, data in relation to gender ideologies and learners of Japanese will be presented.

\section{Choice of verb endings}

Japanese language can be broadly categorised into two levels of speech in daily conversation: polite speech and familiar speech. ${ }^{23}$ Mizutani and Mizutani reveal that most sentences end in desu/masu-style (i.e. polite form) in polite speech, which is generally used in conversations between acquaintances or strangers. ${ }^{24} \mathrm{On}$ the other hand, sentences in conversations between good friends or family tend to end in $d a$ style (i.e. plain form). Although these two styles are not gender-exclusive features, previous studies associate more polite speech with women. ${ }^{25}$ In addition, the style in which learners conversed is of essential importance to this study since more gender differences in Japanese appear in $d a$-style. ${ }^{26}$ Table 2 shows participants' overall choice of verb endings in their discourse practices.

\begin{tabular}{|l|c|c|c|c|c|c|c|c|}
\cline { 2 - 9 } \multicolumn{1}{c|}{} & \multicolumn{2}{c|}{ Pair 1 } & \multicolumn{2}{c|}{ Pair 2 } & \multicolumn{2}{c|}{ Pair 3 } & \multicolumn{2}{c|}{ Pair 4 } \\
\cline { 2 - 9 } \multicolumn{1}{c|}{} & Sophie & Yuri & Olivia & Megumi & Eva & Yoko & Zoe & Risa \\
\hline desu/masu-style & $\checkmark$ & $\checkmark$ & & & & & $\checkmark$ & $\checkmark$ \\
\hline da-style & & & $\checkmark$ & $\checkmark$ & $\checkmark$ & $\checkmark$ & & \\
\hline
\end{tabular}

\section{Table 2: Participants' choice of verb endings}

As Table 2 presents, two pairs chose $d e s u / m a s u$-style, and the other two used $d a$-style as the basic style of their speech, which was consistent within each pair.

In relation to the choice of verb endings, learners revealed their stance on which style they chose in the setting. Sophie and Zoe claimed that they nearly always

\footnotetext{
3 Mizutani and Mizutani, op. cit.

24 Ibid.

25 Ide, op. cit:; Shibamoto, op. cit; Mizutani and Mizutani, op. cit.

26 Ide, op. cit.; Mizutani and Mizutani, op. cit.
} 
used desu/masu-style when they communicate with native Japanese speakers because they did not want to be rude. According to Sophie, the possibility to be offensive to her interlocutors increases when she speaks in $d a$-style. In addition, she further mentioned that during her one-year university exchange, it was difficult to switch her speech style from desu/masu-style to da-style as she became closer to her friends. She said that in the end, this resulted in her retaining desu/masu-style. She revealed that almost all of her Japanese friends were female, and that both Sophie and her Japanese friends conversed in desu/masu-style all the time. Although Zoe had not resided in Japan for a long period, she has a commonality with Sophie in that her Japanese friends were female only, and she also communicated in desu/masu-style.

Different from these two learners, Olivia, who chose $d a$-style as the basic style of her speech, established a rule about choices of verb endings through her long term residence in Japan and changes her speech style according to interlocutors. She revealed that she communicated with Megumi in desu/masu-style at first, and then altered it to $d a$-style shortly, learning Megumi's casual personality. Similarly, Eva described her experience where the speech style changed from desu/masu-style to $d a$-style as she became closer to Yoko.

Native Japanese speakers evaluated the speech styles of their respective addressees in varying ways. Yuri and Risa, whose interlocutors predominantly conversed in desu/masu-style, perceived the style as polite. However, Risa's response carried certain connotations. She had experience teaching Japanese as a second language and knew that learners were more familiar with desu/masu-style because it was the basic style which most textbooks employed. Therefore, Zoe's speech style projected her as a 'learner' to Risa.

Megumi, likewise, referred to her positioning of Olivia as a 'learner' on Olivia's choice of $d a$-style, though it was rather positive in this case. Megumi explained that several learners even at advanced levels sometimes did not understand her Japanese if it was in $d a$-style; therefore, learners who can speak in $d a$-style, including Olivia, gave her the impression that their Japanese level was more advanced. Similar to Risa, she maintained that learners who were learning Japanese in class only, would use 'textbookish' formal speech, even in conversation. Without mentioning the 'learner' category, Yoko evaluated Eva's $d a$-style speech favourably as well. She commented that she changed her speech style from desu/masu-style to $d a$-style after the first meeting with Eva because she wanted to become a closer friend. She appreciated Eva's choice of verb endings because, according to her, it shortened the psychological distance between them. 
As the participants' choices of verb endings and the trajectories towards choices of the basic speech style in this study illustrate, employing desu/masu-style or $d a$-style in each pair on the whole corresponded to the addressees' usage, that is, the style choice was reciprocal.

\section{Pronouns}

All learners as well as native Japanese speakers used watashi 'I' for first-person pronouns in their interactions. While a number of first-pronouns are either exclusively masculine or feminine, watashi is employed by both men and women. ${ }^{27}$ However, Ide indicates that women use the feature in a wider range of contexts. ${ }^{28}$ According to her, watashi appears in semi-formal or informal women's speech; in contrast, the feature is more likely to be identified as formal in men's speech.

As found in previous studies, learners used watashi in informal conversation with their friends. Regarding the choice of learners' first-pronoun, no native Japanese speakers commented that they thought about or noticed the feature during their conversations. However, Megumi, who occasionally used atashi, a less-formal feminine first-pronoun, ${ }^{29}$ pointed out that watashi sounded formal. Risa likewise evaluated watashi as very formal and revealed that she subconsciously adjusted to Zoe and used watashi. Uchi, another feminine informal first-pronoun, which she normally used when conversing with her friends, did not emerge because of Zoe's use of watashi.

\section{Lexical forms}

Several gender-related lexical forms were identified in the learners' discourse. Sophie and Zoe attached the honorific prefixes ' $o$ ' and ' $g o$ ' to a number of nouns e.g. oishasan 'doctor', oyasumi 'holiday', oyōfuku 'clothes', and gokazoku '(your) family'. These prefixes function to 'express the speaker's respect, modesty or politeness. ${ }^{30}$ Although the feature can be employed by both men and women, previous research suggests that the form appears more often in women's speech. ${ }^{31}$ Native Japanese-speaking interlocutors evaluated the learners' usage of this feature as polite.

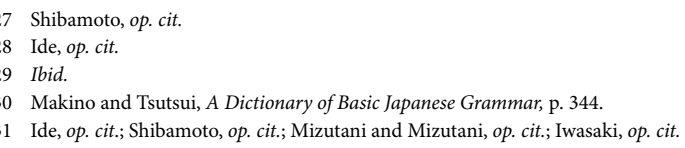


Contrary to the case above, where the learners strove for beautification of their lexical items, Olivia used the slang term maji 'serious' in her speech in line (4) below:

\section{Extract 1}

(1) Megumi: Sono kōhaku de, aka wa, akagumi wa onna no hito nan da kedo, de, shirogumi wa otoko no hito no shingā, shingā.

[In that Koohaku, the red is, the red team is for women, and the white team is for male singers, singers.]

(2) Olivia: $\bar{A}$.

[Okay.]

(3) Megumi: Sorede, dotchi ga katsu ka mitai na no wo tōhyō de maitoshi yaru n da kedo, koko sūnen zutto shirogumi, dansē chìmu ga katte ru, zutto.

[And we vote for one team to decide a winner every year, but the white team, the male team has been winning in the past several years, always.]

$>$ (4) Olivia: Hē, maji de?

[Gee, seriously?]

(5) Megumi: Sō, zettai.

[Yeah, absolutely.]

In relation to this lexical choice, Olivia commented that she doubted that she was thinking about how she was using the feature at the time of conversation. Yonekawa defines this lexicon as a shortened version of the more standard word majime. ${ }^{32}$ According to him, this lexicon is one of those beyond the range of polite Japanese which learners of Japanese would not learn from textbooks in class. He recommends that some of these vocabulary 'require precisely the right moment and situation, and will perhaps be more useful as part of your passive vocabulary rather than the active. ${ }^{33}$ Given that previous studies indicate that women tend to use politer words, ${ }^{34}$ slang would not be considered to be 'women's language'. Megumi described her evaluation toward Olivia's articulation in the following way:

\section{Extract 2}

I notice this feature every time (Olivia) ${ }^{35}$ uses it because the vocabulary is rather masculine, and is not a word that I would use. It sounded strange when I first heard it, but I am getting used to it recently.

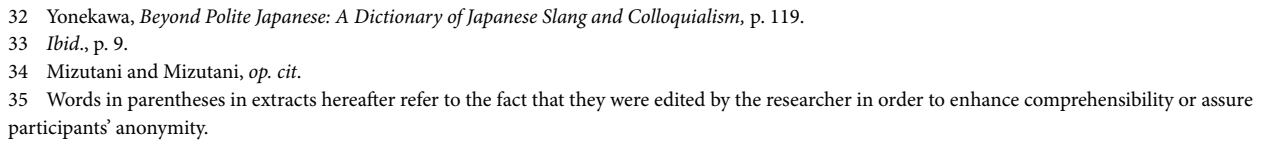


The above extract illustrates that Megumi noticed Olivia's utterance 'maji' during their conversation. In addition, her impression towards the usage has shifted from negative to neutral over time, though she still noticed when the lexicon was articulated, even after hearing it several times.

\section{The forms of request/command}

Among a range of command forms in Japanese, several types are categorised as 'men's language', reflecting a rough and straight-forward impression. ${ }^{36}$ Eva produced one of these masculine command forms in line (6):

\section{Extract 3}

(1) Yoko: Nichiyōbi wa nani shita kke? Nichiyōbi wa toshokan ni kite... [What did I do on Sunday? I came to the library...]

(2) Eva: $\bar{E}$ ? Mata toshokan?

[Gee, the library, again?]

(3) Yoko: Asainmento no...

[For an assignment...]

(4) Eva: $\bar{E}$ ? Benkyō bakkari.

[Gee, you're into studying.]

(5) Yoko: $\quad$ Ieieie, date uchi de shinai mon.

[No, no, no, because I don't study at home.]

$>$ (6) Eva: Uso yūna.

[Don't tell a lie.]

(7) Yoko: Honto, honto.

[I mean it, I mean it.]

Upon hearing this utterance which was replayed in the stimulated-recall interview, Eva claimed that she uttered it naturally and had no comment on the usage.

Different from Eva, her interlocutor Yoko did notice the feature during their conversation. Yoko revealed how she felt about Eva using the command form as follows:

36 Ide, op. cit:; Suzuki, 'Josēgo no honshitsu - Tēnēsa, hatsuwa kōdō no shiten kara -'. 


\section{Extract 4}

(Eva) sometimes uses this kind of masculine speech. I got surprised when I heard these expressions for the first time. I felt like 'oh, she's a woman, but using masculine speech....it was rather negative impression. But the impression has changed because I hear these usages many times, and I now understand it's her way of speaking...though I notice the feature even now when I speak with her.

As the extract above demonstrates, Yoko's stance towards Eva's masculine speech by the learner has changed from 'surprise' to 'acceptance'. However, use of this feature still attracts her attention, similar to the case of Megumi and Olivia in the previous section.

\section{Sentence-final particles}

A number of SFPs are employed in conversational Japanese to express the speaker's modality, that is, feelings and attitudes with respect to the listener. ${ }^{37}$ Apart from Zoe's usage, these features appeared in participants' discourses to some degree, regardless of the use of $d e s u / m a s u$-style or $d a$-style. However, SFPs in the latter style project gender differences prominently. Among several gender-related SFPs that were identified in previous research, Olivia, who conversed in da-style, produced two kinds of SFPs in her conversation. The first SFP is indicated in turn (2) below:

\section{Extract 5}

(1) Megumi: ...ninjin toka burokkorī toka, akirakani nama nanoni, sonna mono tabe nagara aruite ru kara, 'e? usagi?' toka tte omo tte

[...I see people eating carrots, broccoli etc. on my way. (These vegetables are) obviously raw, but people are walking, eating them. So I thought "Huh? (Are they) rabbits?"]

(2) Olivia: Sō yo, takusan taberu to yoru demo mieru, iya, uso da kedo [That's true. Eat a lot (of vegetables), and you can see even at night. No, just kidding]

(3) Megumi: Hahahaha

[Hahahaha]

37 Mizutani and Mizutani, op. cit. 
Olivia accounted for this usage, describing that she thought 'sō yo' was the da-style of 'sō desu yo' in desu/masu-style. In fact, changing 'sō desu yo' to 'sō yo' not only altered the speech style, as she recognised, but also gave a feminine impression to the articulation. The SFP ' $y o$ ' is neutral since both men and women use the feature. ${ }^{38}$ However, in Olivia's case, SFPs used with the omission of the assertive copula ' $d a$ ' is categorised as feminine speech. ${ }^{39}$

Another SFP which previous research classifies as 'women's language' was identified in Olivia's speech in line (2):

\section{Extract 6}

(1) Megumi: Hōmusutei no toki wa terebi atta $n$ da kedo

[I had a TV when I was home-staying.]

(2) Olivia: $\bar{A}$, hōmusutei shite ta no?

[Oh, were you home-staying?]

(3) Megumi: Sōsō, saisho no ichi nen wa hōmusutei da tta

[Yeah, yeah, I was home-staying during the first year.]

Olivia accounted for this usage, indicating that she used the feature simply to ask a question. Although not an exclusively female feature, Makino and Tsutsui, and Mizutani and Mizutani claim that SFP ' $n o$ ' in an interrogative sentence, as seen in Olivia's discourse, is employed more often by women. ${ }^{40}$

In relation to the appearance of these two features in Olivia's discourse, Megumi reported that she felt nothing during or after their conversation.

\section{Learners' awareness of gender ideologies}

When asked about characteristics of gender differences in Japanese, Sophie, Olivia, and Eva described four different types of features: verb endings, pronouns, lexical forms, and SFPs. They explained how gender differences appeared in each category and what kind of image these features projected. In accordance with previous studies on gender differences in Japanese, they indicated that those classified as 'women's language' gave

38 Ide, op. cit.; Shibamoto, op. cit.; Mizutani and Mizutani, op. cit.; McGloin, op. cit.

39 Mizutani and Mizutani, op. cit.; McGloin, op. cit.; Suzuki, op. cit.; Iwasaki, op. cit.

40 Makino and Tsutsui, op. cit.; Mizutani and Mizutani, op. cit. 
the impression of politeness and softness, whereas 'men's language' sounded rough. In addition, all of them were aware to some degree of social expectations on them as females to employ 'feminine' speech. Moreover, they pointed out deviant usage of gendered features where women employ 'men's language' and vice versa. However, Zoe revealed that she did not recognise such differences, except for having a broad idea that women spoke more politely, and a few SFPs that she noticed were peculiar to men.

Regarding the learners' different understandings of gendered features of Japanese, three main mediums were identified that provided learners with these ideologies: experience in Japan, popular culture, and Japanese classes. These are further explored in the following sections.

\section{Gender ideologies and experience in Japan}

As Table 1 demonstrated, all learners have stayed in Japan for varying lengths and for different purposes. Sophie indicated that her experience in Japan enabled her to notice that women actually use politer language than men in general and promoted her understanding of gender differences in Japanese when interacting with both genders. Such observation did not occur in her home country where she had female Japanese friends only. She shared an episode where her consciousness towards gender differences was raised:

\section{Extract 7}

I once said 'hara hetta', not knowing the nuance the word had. Then my friends laughed and told me the word didn't suit me, and then I realised that was not a word for women. I remember this experience well because I got embarrassed.

She further explained that she made sure not to use that kind of masculine speech thereafter.

Similar to Sophie, Olivia experienced a prolonged stay in Japan on a university exchange program for three years altogether, interacting with Japanese people (predominantly male) whose ages ranged from their mid-twenties to their sixties. She observed a great amount of not only linguistic features but also paralinguistic features and behaviour such as tone of voice and clothing which were conspicuous in relation to certain women. Moreover, she described an incident where the topic of gender-related language occurred in a conversation with her colleagues as follows: 


\section{Extract 8}

(My colleagues) praised my Japanese as being beautiful....when I said 'Oh, I wish I could say things like (men's language)'...they said it was good that I didn't talk like that...they said...it's good you don't because that would not be nice.

Contrary to Sophie, Olivia revealed her disappointment to hear that she was not supposed to use masculine speech.

Although both Eva and Zoe have been to Japan as well, they explained that they did not recognise gender differences in Japanese during their in-country experiences. Eva explained that the trip she took during a university holiday was rather a sojourn where her main interactions with native speakers were as a customer and the Japanese salespeople spoke in desu/masu-style. Zoe also did not notice gendered features during her sojourn experience in Japan for different reasons. Unlike the other three learners, she stayed in Japan on a high school exchange with her Japanese at a beginner level. She was hardly able to converse on a sentence level, resulting in her communicating with simple words, utilising a dictionary. This may in part help to explain Zoe's lower level of recognition of gendered features.

\section{Gender ideologies and popular culture}

As a means of mediation of gender ideologies, popular culture plays a significant role. All learners except Zoe answered that at the time this study was conducted they interacted with Japanese language through popular culture such as TV dramas, TV variety shows, anime, and comics. In the case of Sophie, she started watching Japanese anime and dramas as a hobby before entering university and beginning to study Japanese. According to her, these mediums familiarised her with various aspects of conversation including gender differences in various contexts. Olivia likewise reported that she noticed gendered features when she heard casual conversations in da-style through these media. Similar to Sophie, Eva developed her interest in anime when she was in early secondary school. According to her account, through this she became accustomed to masculine speech since most of the characters in anime were male.

Given that gender differences in these media are emphasised to the extent where they do not conform to actual language use in everyday conversation of this era, as Mizumoto argues, it is reasonable that learners promoted gender ideologies through popular culture in some form. ${ }^{41}$

41 Mizutomo, 'Terebi dorama to jitsushakai ni okeru josē bunmatsushi shiyō no zure ni miru jendā firuta'. 


\section{Gender ideologies and Japanese class}

Apart from the out-of-class activities indicated above, Japanese classes provided all learners with information on gender ideologies to some degree. Olivia shared her experiences when she and her classmates were taught gender differences in Japanese in class; teachers gave a dialogue that contained both male and female types of speech, of which each gender employed different pronouns and SFPs. In addition, she mentioned that teachers taught students that women speak politely and cautioned them not to sound like the opposite gender because it was a bad practice. When asked her attitude at that time, she once again expressed her dissatisfaction at the constraint for her not to employ 'men's language.' Correspondingly, Eva explained that she learned gender differences in the same way as Olivia, including the caveat on usage from teachers. However, several teachers actually pointed out that her way of speaking was quite masculine.

Zoe scarcely recognised differences between men's and women's speech in comparison with the other learners in this study, as indicated before. However, she accounted for an instance where she did notice that Japanese women were speaking much more politely than men when she watched a video about the use of honorifics in the workplace. In addition, Zoe described a case in which she noticed masculine SFPs when Japanese comics were covered in class. However, she retained a vague idea about these SFPs because the focus of the class was not on these features and so she did not try to discover characteristics of these segments.

\section{Discussion}

\section{Occurrence of gendered features in learners' discourse practices}

As indicated earlier, a range of gender-related features were located in the learners' conversational speech. These features varied in character depending on the learner in terms of degree of frequency and whether they were 'men's language' or 'women's language.' With relatively similar objectives to the current study, Asada investigated learners' production of SFPs, which is the only comparable study available to date. ${ }^{42} \mathrm{He}$ argues that no significant deviation from 'women's language' was observed in discourse by female learners of Japanese in his study. Although a number of differences in the settings of these two studies should be taken into account, the findings of my study conform to his claim only if paying attention to SFPs. However, several other gendered features, which were masculine enough to surprise or cause a feeling of strangeness to the learners'

42 Asada, op. cit. 
interlocutors, also appeared in this study. In addition, the current study identified two feminine SFPs that did not appear in or were not the focus of Asada's study. ${ }^{43}$

In relation to the (non-)appearance of gendered features, the current study examined learners' awareness of 'men's language' and 'women's language' as a result of gender ideologies and also considered how these ideologies had been established. This study revealed that the degree of awareness and mediums through which this awareness had been constructed varies depending on learners' backgrounds and experiences. Regarding to the extent to which learners recognise these ideologies, I propose that various factors are related: learners' level of Japanese, their length of stay in Japan, interaction with popular Japanese culture, and exposure to gendered features in Japanese classes. The first two factors are congruent with the findings of Thomson and Iida's study in which learners' perceptions towards gendered features were surveyed quantitatively. ${ }^{44}$

\section{Gender ideologies and learners' language negotiation}

The qualitative approach of the present study resulted in a deeper understanding of how gender ideologies affect learners in different ways. Not all female learners in this paper employed 'women's language' because they were women.

For Sophie, it was natural for her to use 'women's language' because she prefers politer language. As seen from the case where she accidentally used masculine speech and felt embarrassed, 'men's language' did not match her account of her character. She claimed that women using 'men's language' sounded rough; therefore, she made sure not to use speech which was associated with men. This illustrates that she made her language choice according to her personality, being aware of what kind of discourse is expected of her. In accordance with her account, Sophie's utterances were polite on the whole, as evaluated by her interlocutor, with no masculine speech identified.

Olivia expanded her awareness of gender ideologies through different kinds of media, with her extended stay in Japan being the most prominent channel. However, she was particularly different from Sophie in that she held admiration for 'men's language'. Language peculiar to men was perceived by Olivia as different from that of women which she sensed was similar to the style of speech in the textbooks and thus felt boring; therefore, men's speech was appealing to her. Despite her appreciation of masculine speech, she expressed her hesitation to produce these features because of 
social constraints. Olivia knows that for her, as a woman, employing masculine speech is socially unacceptable through her experiences where native Japanese speakers pointed this out. As a result of weighing resistance against acceptance of the norm, she decided to follow the latter. However, there appeared to be a discrepancy between this decision and her actual discourse practices in her interaction, as masculine features did in fact occur. She acknowledged the possibility that 'men's language' might sometimes accidentally appear in her speech since most of her friends in Japan were male, and they influenced her discourse. It could be assumed that such a case arose in the present study, reflecting the fact that she was conversing in $d a$-style with a friend whose personality she considers as very casual. A setting like this may have emancipated her from consciously monitoring her speech trying to be in accordance with the social expectations.

With respect to masculine speech, Eva shared a commonality with Olivia in that both of them were accustomed to 'men's language' to some degree. Whereas Olivia familiarised herself with this style through interaction with male Japanese friends, most of Eva's knowledge or awareness of gender differences are mainly derived from anime. Eva claimed that she heard masculine speech to a great extent through this medium, which resulted in her subconsciously using these features, as seen in Olivia's case. Different from the above two learners, she explained that even though she knew her way of speaking was masculine, as several teachers had pointed out, she did not intend to change her style. She does not deliberately use masculine features, rather they are produced naturally beyond her control. In addition, she commented that she does not mind her masculine mannerisms, though unintended, because they do not conflict with the image she wants to project. Correspondingly, masculine speech occurred in her discourse practice.

In contrast to the three learners described above, Zoe had not experienced significant negotiation of language choice in regards to gender-related features in Japanese, and had limited awareness of gender ideologies. Her consciousness was directed towards conversing politely on the whole so that she did not offend her native Japanese interlocutors.

As seen from the four learners' cases above, gender ideologies are influential in learners' discourse practices in that these ideologies play a role in providing learners with resources for them to negotiate their language use. Moreover, these ideologies that project the social norms in Japan function to restrict their discourse practices as well, as seen in the case of Olivia, who wanted to use 'men's language' but tried not to because of social expectations. Gender ideologies influence learners' discourse practices as they utilise gender ideologies as a means to express themselves according to their personalities and their relationships with those with whom they interact. 
These negotiations of language use by learners being influenced by gender ideologies demonstrate that Nakamura's Dynamic Model of Language and Gender Studies applies not only to native Japanese speakers but also to learners of Japanese to some degree. ${ }^{45}$

By indicating 'to some degree, I argue that the gender ideologies that learners are aware of are incomplete and that how much negotiation occurs depends on the extent of their awareness of these concepts. Some are more familiar with the ideologies of one gender's category, while the others recognised little gender difference in Japanese. In addition, several learners were not aware of the nuances of gendered features and how their interlocutors judged these utterances in their interactions. Considering these aspects, each learner's discourse practices may greatly transform their character as they accumulate awareness towards gender ideologies.

\section{Marked masculine speech and unmarked feminine speech}

Examining how native Japanese speakers evaluated gendered features in learners' speech, one commonality among them emerges. That is, masculine speech produced by the female learners was considered marked by their female Japanese interlocutors, while feminine speech was unmarked. The native speakers utilised gender ideologies to evaluate learners' gendered features. Native speakers' comments on masculine features are common in cases where the learners' usage deviated from the norm that 'men's language' is not for women. In addition, the stimulated-recall interviews revealed that native Japanese speakers noticed masculine features during their interaction, even after they had heard learners conversing in similar masculine speech, while feminine speech was unnoticed. Although native speakers' evaluation of female learners' masculine speech had changed from negative to neutral, these language uses remained marked.

Here, one question arises: what are gender ideologies that are so central to one's language negotiation and its evaluation? Regarding how these ideologies have been constructed, Inoue associates establishment of the concept of Japanese 'women's language' with the early 20th century, where Japan underwent unprecedented social reform: Meiji Restoration. ${ }^{46}$ Striving towards modernisation (or Westernization), the government endeavoured to promote women's education under the principal of 'a good wife and wise mother'. The language that those educated 'modern' women employed was stereotypically represented and circulated in the rapidly-developed print media of the era, which as a result obtained the status of 'women's language. 47 According to

\footnotetext{
Nakamura, 'The dynamic model of language and gender studies'.

46 Inoue, 'Gender, language, and modernity: toward an effective history of Japanese women's language'.
}

47 Ibid. 
Inoue, this 'women's language' involved imagining and was chosen at the discretion of writers at that time; therefore, it is 'no one's language' but 'disembodied language'. ${ }^{48}$ That is what Nakamura calls 'women's language' being created. ${ }^{49}$ Despite absence of the real voice, this 'women's language' gradually consolidated its social position as hegemonic gender ideology, reflecting control at societal level. With growing nationalism during and after the following world wars, a claim was made that the feature was peculiar in Japanese; hence superiority of Japan and its language. ${ }^{50}$ In addition, 'women's language' was embellished with praise such as traditional and beautiful, and resulted in far more dissemination in the community.

Considering the dialectic relationship among social structures, gender ideologies, and discourse practices, these three aspects do not remain static but dynamic. It is true that gender ideologies have been transforming, reflecting the change in the structure of Japanese society as Nakamura indicates. ${ }^{51}$ However, in accordance with Iwasaki's argument, deviant usage of gender-related language is marked, even today, where neutralisation of gender differences in Japanese is considered to be in progress. ${ }^{52}$ That is to say, though being transformed, there still exist dominant gender ideologies, and following and reproducing these ideologies is considered to be 'correct'; therefore, as Yukawa and Saito argue, shelters the speaker from criticism. ${ }^{53}$ Discourse becomes marked because it conflicts with hegemonic ideologies. In addition, it is women who are more bounded with the norm and carry social expectations on their shoulders to employ 'traditional and beautiful women's language'. Not only men or the relatively aged who are generally seen as critical of the non-normative language use by women, ${ }^{54}$ but also female friends, as seen in this study, could be the agents who maintain such normative ideologies by accepting them rather than actively subverting.

\section{Marked learners' speech}

In addition to masculine and feminine categories, one more key category emerged with respect to native speakers' evaluation of learner's gendered features. That is, the category of 'learner'. Despite all learners who participated in this study being at advanced levels, most native Japanese speakers consciously or subconsciously adjusted their speech to help the learners comprehend their conversation.

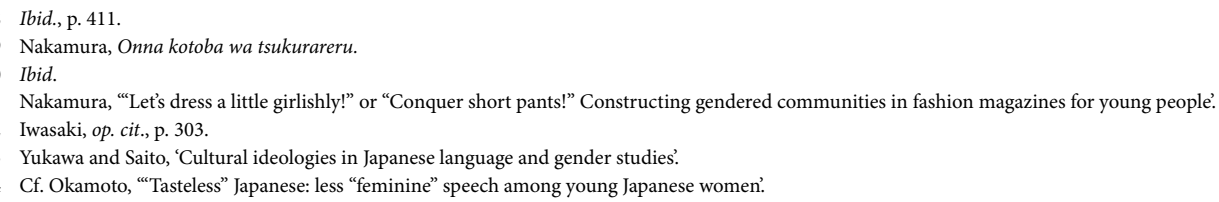


Whether learners employed the desu/masu-style or da-style may hinge on the relevance of the category of 'learner' in the interaction. While conversing in desu/masustyle shelters learners from being rude, as Yuri and Risa indeed evaluated the style as polite, it may also keep learners from achieving a breakthrough to develop familiarity with their interlocutors. Indeed, three native Japanese speakers, Megumi, Yoko, and Risa, suggested that they favoured conversing in $d a$-style with friends. In contrast with their interlocutors' expectations, Sophie and Zoe, even at their advanced levels, retained the $d e s u / m a s u$-style with a firm commitment to being polite.

The perception of their addressees as 'learners' by the native Japanese speakers poses a question as to how they evaluated learners' gendered features. To be more precise, the existence of the category of 'learner' may have affected the way native speakers evaluated learners' speech. As indicated earlier, variety in discourse practices, that is, speech that does not necessarily conform to the norm, has been reported in several studies. Indeed, all native speakers in the current study acknowledged this deviant usage of gendered features, indicating several female friends of theirs actually used 'men's language.' The point is, despite the fact that they were familiar with this nonnormative usage to some extent, learners' masculine speech was marked.

When her rather masculine language use in her conversation with the learner was pointed out, Megumi explained that the usage was a slip of the tongue and she usually would not use such speech. Interestingly, the exact same speech pattern appeared again later in the interaction. She was the one who evaluated her addressee's masculine feature as sounding strange. Although it is unsure if her use of masculine features was simply subconscious or she was performing by her minimising of these features during the interview to meet the 'social desirability' criteria, ${ }^{55}$ i.e. women should not use 'men's language', this instance is worth taking into account. As Thomson argues, native Japanese speakers have a tendency to expect learners of Japanese to speak 'correctly. ${ }^{56}$ In the context of these findings, native Japanese speakers' perceptions towards their addressees as 'learners' may have affected their evaluation of learners' masculine gendered features in a rather negative way. 


\section{Implications}

\section{Providing learners with knowledge}

SFPs appeared to be perplexing features for several learners regardless of whether they were gendered or not. Olivia and Zoe explained that they used a guessing strategy when certain SFPs occurred in native Japanese speaker's discourse when they were conversing. Both of them maintained that Japanese classes did not sufficiently focus on these features, which as a result made them unsure of the meaning or uncomfortable in producing the forms themselves. Although difficult to verify the reliability of their accounts, their concern may reflect the actual condition to some degree, considering most classes would employ desu/masu-style where fewer SFPs occur. In addition, SFPs would not cause communication breakdowns as these features mainly express speakers' modality. That is, learners can hold a conversation without understanding the SFPs used. For these reasons, SFPs may not have been given significant attention in classes.

Concerning SFPs and the learners' JFL curricula, Olivia showed her willingness to learn the features because according to her 'conversation without SFPs means there is no flavour to the language in a way' Similarly, Zoe noticed her classmates using the features, which she thought made their discourse sound natural. She also confessed that she struggled with a feeling of inferiority in the class because many of her classmates had resided in Japan for long periods, and there was a wide gap between their Japanese proficiency and hers. According to her, use of SFPs was one of those differences.

Learners may develop their desire to project their individualities utilising language, as their level of Japanese proceeds. Although there would be various ways, providing knowledge of SFPs as a tool would be one effective way to achieve such an aim. Moreover, Japanese classes would benefit learners if they convey not only knowledge but also opportunities to actively think about the feature, as Thomson and Otsuji point out. ${ }^{57}$ Discussing variety in discourse practices beyond traditional 'men's language' and 'women's language' may raise learners' consciousness towards gender differences in Japanese, which would lead them to negotiate their subjectivities in utilising these features.

57 Thomson and Otsuji, 'Bijinesu Nihongo kyōkasho to jendā no tamenteki kōsatsu'. 


\section{Providing learners with contexts}

Assuming that gender differences appear more in the da-style, as former studies indicate, limited exposure to the style could be one reason that keeps learners from familiarising themselves with gender differences in Japanese. Although various complex factors influence one's choice of speech style, native Japanese speakers may employ desu/masu-style as a result of adjusting to the learners' style or learners' not being able to communicate in $d a$-style, as several native Japanese speakers in the current study indicated. In addition, the classroom context is fixed for teachers and students and it is where desu/masu-style is mostly employed. Consequently, I would argue that the classroom context should not be static but dynamic.

A number of methods to bring context into the classroom have been explored. These include projects that involve native Japanese speakers in the community, ${ }^{58}$ visitor sessions where peers at advanced levels participate, ${ }^{59}$ and popular culture such as anime ${ }^{60}$ and J-pop. ${ }^{61}$ As a result of these forms of media being incorporated into the classroom, learners obtain exposure to various contexts which lead them to use and produce different speech styles, eventually increasing awareness of gender ideologies. These designs would provide learners with opportunities to adjust their speech style, depending on their interlocutors, beyond learners' relying frequently on desu/masustyle speech. In addition, authenticity of these resources may also enhance learners' motivation and lead to out-of-class learning.

\section{Conclusion}

The present study focused on what kinds of gender-related features female learners at advanced levels produce when they converse with native Japanese-speaking friends. Individual discourse practices revealed that each learner possesses a unique character in their utterances, reflecting their individual awareness of gender ideologies and their negotiation of language use against the backdrop of social expectations. The existence of such norms provided learners with a resource for their discourse practices, allowing them to choose forms that aligned with their identities, however, the norms functioned as a restriction to some degree as well. At the same time, a lack of awareness of gender ideologies emerged as an issue which kept them from fully and actively engaging in exploring their subjectivities which negotiating language use would result in. In addition, this study pointed out that native Japanese speakers

\footnotetext{
8 Imura, 'Chiki shakai no Nihongo washa no shien sanka ni yoru chūkyūsha muke purojekuto'

59 Thomson and Masumiso, '`Senpai ga kimasu! 」- I reberu kyōdō no sēka’.

60 Makino, 'Nihongo •Nihon bunka kyōiku to anime $-{ }^{『}$ Sen to Chihiro no Kamikakushi』no bāi - '.

61 Iida, 'Kashi bunseki de shiru Nihon - J-pop no kōsu yori'.
} 
utilised these ideologies as the basis for their judgements on learners' gendered features in their interaction.

Although the present study obtained interesting insights, several issues remain as limitations, mostly concerning the interview methodology. As indicated earlier, Sophie and Zoe were sensitive to politeness and not being offensive to a great extent when native Japanese speakers were concerned. Therefore, I, as a native Japanese speaking interviewer, may have affected the way they responded i.e. they might have censored information. The same applies to the native Japanese speaking participants. As gender ideologies socially privilege women using 'women's language' and relegate women employing 'men's language' to a deviant categorisation, participants may possibly have 'performed' for the researcher if they perceived the format of the audiorecorded interview as being rather formal. ${ }^{62}$

Despite several limitations, the current study resulted in interesting findings on gender characteristics in learners' conversational Japanese, several of them having not been explored thus far. Since all participants in this study were female by chance, further research targeting male pairs and mixed-gender pairs will be required to deepen our understanding of the topic. In addition, one single learner's gendered language variation depending on interlocutors, contexts, or mediums may be another focus that calls for investigation.

Comprehending gender differences in Japanese is demanding for learners of Japanese since these differences not only concern linguistic or paralinguistic features but also involve social expectations and variations depending on context. Moreover, these differences are dynamic in nature, reflecting ever-changing characteristics of society. Native Japanese speakers, who centre themselves in Japanese society, are well aware of gender ideologies since these ideologies are imbued through a lifetime of experience such as education at school or home. Consequently, gender ideologies are one aspect that learners need to develop to a high level of awareness. Particular attention must be paid to those in a JFL setting who lack exposure to these ideologies. Incorporating this aspect of language into the classroom in a non-traditional, creative way may result in great opportunities for learners to reflect on Japanese language, society, and their subjectivity as a user and learner of Japanese.

62 Block, 'Social constraints on interviews'. 


\section{References}

Abe, H., 'Lesbian bar talk in Shinjuku, Tokyo', in Okamoto, S. and Shibamoto, J. S. (eds.), Japanese Language, Gender, and Ideology: Cultural Models and Real People (New York and Oxford: Oxford University Press, 2004), pp. 205-221.

Abe, K., 'Mottomo sēsa no aru gengo - gengo no sēsa no tajūkōzō', Gekkan Gengo, vol. 27, no. 5 (1998), pp. 72-76.

Asada, H., 'Daini gengo to shite no Nihongo no otoko kotoba, onna kotoba - danjosa wo shimesu bunmatsu hyōgen ni oite no Nihongo gakushūsya no sansyutsu, juyō nōryoku - ', Nihongo Kyōiku, vol. 96, pp. 25-36.

Block, D., 'Social constraints on interviews', Prospect, vol. 10, no. 3 (1995), pp. 35-48.

Dörnyei, Z., Research Methods in Applied Linguistics (Oxford: Oxford University Press, 2007).

Ide, S., Onna no Kotoba Otoko no Kotoba (Tokyo: Nihon Kēzai Tsūshinsha, 1979).

Iida, S., 'Kashi bunseki de shiru Nihon - J-pop no kōsu yori', in Thomson, C. K. (ed.), Gakushūsha Shutai no Nihongo Kyōiku - Ōsutoraria no Jissen Kenkyū (Tokyo: Coco Publishing, 2009), pp. 179-195.

Imura, T., 'Chiki shakai no Nihongo washa no shien sanka ni yoru chūkyūsha muke purojekuto', in Thomson, C. K. (ed.), Gakushūsha Shutai no Nihongo Kyōiku - Ōsutoraria no Jissen Kenkyū (Tokyo: Coco Publishing, 2009), pp. 69-83.

Inoue, M., 'Gender, language, and modernity: toward an effective history of Japanese women's language', American Ethnologist, vol. 29 (2002), pp. 392-422.

Iwasaki, S., Japanese (Amsterdam: John Benjamins Publishing Company, 2002).

Makino, S. and Tsutsui, M., A Dictionary of Basic Japanese Grammar (Tokyo: The Japan Times, 1986).

Makino, S., 'Nihongo •Nihon bunka kyōiku to anime - ${ }^{『}$ Sen to Chihiro no Kamikakushi』no bāi - ', in Hatasa, Y. (ed.), Gaikokugo to shite no Nihongo Kyōiku - Takakuteki Shiya ni Motoduku Kokoromi (Tokyo: Kuroshio Shuppan, 2008), pp. 61-81.

McGloin, N. H., 'Sex difference and sentence-final particles', in Ide, S. and McGloin, N. H. (eds.), Aspects of Japanese Women's Language (Tokyo: Kuroshio Publishers, 1991), pp. 23-41.

McGloin, N. H., 'Shūjoshi', in Ide, S. (ed.), Josēgo no Sekai (Tokyo: Mēji Shoin, 1997), pp. 33-41.

Mizumoto, T., 'Terebi dorama to jitsushakai ni okeru josē bunmatsushi shiyō no zure ni miru jendā firuta', in Sasaki, M. and Nihongo Jendā Gakkai (eds.), Nihongo to Jendā (Tokyo: Hitsuji Shobō, 2006), pp. 73-94.

Mizutani, O. and Mizutani, N., How to be Polite in Japanese (Tokyo: The Japan Times, 1987).

Nakamura, M., 'The dynamic model of language and gender studies', Shizen, Ningen, Shakai, vol. 32 (2002), pp. 1-26.

Nakamura, M., "Let's dress a little girlishly!” or “Conquer short pants!” Constructing gendered communities in fashion magazines for young people, in Okamoto, S. and Shibamoto, J. S. (eds.), Japanese Language, Gender, and Ideology: Cultural Models and Real People (New York and Oxford: Oxford University Press, 2004), pp. 131-147.

Nakamura, M., “Onna kotoba” wa tsukurareru (Tokyo: Hitsuji Shobō, 2007).

Neustupný, J. V., 'The follow-up interview', Japanese Studies Association of Australia Newsletter, vol. 10, no. 2 (1990), pp. 31-34. 
Ohara, Y., 'Shakai onsēgaku no shiten kara mita Nihonjin no koe no kōtē’, in Ide, S. (ed.), Josēgo no Sekai (Tokyo: Mēji Shoin, 1997), pp. 42-58.

Ohara, Y., 'Finding one's voice in Japanese: a study of the pitch levels of L2 users', in Pavlenko, A., Blackledge, A., Piller, I., and Teutsch-Dwyer, M. (eds.), Multilingualism, Second Language Learning, and Gender (Berlin, Germany: Mouton de Gruyter, 2001), pp. 231-254.

Okamoto, S., “Tasteless” Japanese: less “feminine” speech among young Japanese women', in Hall, K. and Bucholtz, M. (eds.), Gender Articulated (New York, NY: Routledge, 1995), pp. 297-325.

Okamono, S., 'Social context, linguistic ideology, and indexical expressions in Japanese', Journal of Pragmatics, vol. 28 (1997), pp. 795-817.

Okamoto, S. and Shibamoto, J. S., 'Introduction', in Okamoto, S. and Shibamoto, J. S. (eds.), Japanese Language, Gender, and Ideology: Cultural Models and Real People (New York and Oxford: Oxford University Press, 2004), pp. 3-20.

Piller, I. and Pavlenko, A., 'Introduction: multilingualism, second language learning, and gender', in Pavlenko, A., Blackledge, A., Piller, I., and Teutsch-Dwyer, M. (eds.), Multilingualism, Second Language Learning, and Gender (Berlin, Germany: Mouton de Gruyter, 2001), pp. 1-13.

Reynolds, K. A., 'Gengo to sēsa no kenkyū - genzai to shōrai', in Ide, S. (ed.), Josēgo no Sekai (Tokyo: Mēji Shoin, 1997), pp. 199-216.

Shibamoto, J. S., Japanese Women's Language (Orlando, FL: Academic Press, 1985).

SturtzSreetharan, C., 'Japanese men's linguistic stereotypes and realities: conversations from the Kansai and Kanto regions', in Okamoto, S. and Shibamoto, J. S. (eds.), Japanese Language, Gender, and Ideology: Cultural Models and Real People (New York and Oxford: Oxford University Press, 2004), pp. 275-289.

SturtzSreetharan, C., 'Gentlemanly gender?: Japanese men's use of clause-final politeness in casual conversations', Journal of Sociolinguistics, vol. 10, no.1 (2006), pp. 70-92.

Suzuki, M., 'Josēgo no honshitsu - Tēnēsa, hatsuwa kōdō no shiten kara -', in Ide, S. (ed.), Josēgo no Sekai (Tokyo: Mēji Shoin, 1997), pp. 59-73.

Thomson, C. K., 'Who is to say "Your Japanese is incorrect"? Reflection on "correct" Japanese usages by learners of Japanese', Japanese Studies, vol. 30, no. 3 (2010), pp. 427-441.

Thomson, C. K. and Iida, S., 'Nihongo kyōiku ni okeru sēsa no gakushū - Ōsutoraria no gakushūsha no ishiki chōsa yori - ', Sekai no Nihongo Kyōiku, vol. 12 (2002), pp. 1-20.

Thomson, C. K. and Masumiso, H., ‘'Senpai ga kimasu! 」- I reberu kyōdō no sēka’, in Thomson, C. K. (ed.), Gakushūsha Shutai no Nihongo Kyōiku - Ōsutoraria no Jissen Kenkyū (Tokyo: Coco Publishing, 2009), pp. 31-46.

Thomson, C. K. and Otsuji, E., 'Bijinesu Nihongo kyōkasho to jendā no tamenteki kōsatsu', Sekai no Nihongo Kyōiku, vol. 19 (2009), pp. 49-67.

Yonekawa, A., Beyond Polite Japanese: A Dictionary of Japanese Slang and Colloquialism (Tokyo: Kodansha International, 1992).

Yukawa, S. and Saito, M., 'Cultural ideologies in Japanese language and gender studies', in Okamoto, S. and Shibamoto, J. S. (eds.), Japanese Language, Gender, and Ideology: Cultural Models and Real People (New York and Oxford: Oxford University Press, 2004), pp. 23-37. 